\title{
Operative Technique for Correction of Gigantomastia, Using the Superior Pedicle, with Special Care for the Nipple-Papillary Grafts: A 13-Year Retrospective Study
}

\author{
José Humberto Cardoso Resende ${ }^{1,2,3 *}$, Lucilia Feliciano Marques di Carlantônio1, \\ Luiz Célio Martins Freitas ${ }^{1,4}$, Teresa Tonini ${ }^{5,6}$, Nébia Maria Almeida de Figueiredo7, \\ Luiz Carlos Santiago ${ }^{7}$ \\ ${ }^{1}$ Nursing and Biosciences, Federal University of Rio de Janeiro State (UNIRIO), Rio de Janeiro, Brazil \\ ${ }^{2}$ Member of the Brazilian Society of Plastic Surgery (SBCP), Rio de Janeiro, Brazil \\ ${ }^{3}$ Brazilian College of Surgeons (CBC), Rio de Janeiro, Brazil \\ ${ }^{4}$ President of the Catheters committee of the National Cancer Institute (INCa), Rio de Janeiro, Brazil \\ ${ }^{5}$ Public Health from State of Rio de Janeiro University (UERJ), Rio de Janeiro, Brazil \\ ${ }^{6}$ Coordinator of the Post-graduate Program in Nursing and Bioscience of UNIRIO, Rio de Janeiro, Brazil \\ ${ }^{7}$ Nursing, Federal University of Rio de Janeiro State (UNIRIO), Rio de Janeiro, Brazil \\ Email: ${ }^{\text {jiresen99@hotmail.com }}$
}

Received 17 June 2015; accepted 24 July 2015; published 27 July 2015

Copyright (C) 2015 by authors and Scientific Research Publishing Inc.

This work is licensed under the Creative Commons Attribution International License (CC BY).

http://creativecommons.org/licenses/by/4.0/

c) (i) Open Access

\section{Abstract}

This is a retrospective study on gigantomastia correction in obesity facing the technique of nippleareolar grafts and its complexity. The main question is the technical-surgical care during its execution aiming to achieve reparative results that can return to these women the desire to live with better quality of life and health. Method: We performed a retrospective study of all obese patients with severe gigantomastia who underwent reduction mammaplasty with an operative technique using the superior pedicle, with special care for the nipple-papillary grafts. The study was carried out at a single institution between 2001 and 2013, in a total of 30 cases. This operative technique was presented at first time in 1980 , with no changes up to now. We emphasized the perfect decortication of the areola and nipples until they were translucent after the maneuvers of Schwartzman and subsequent grafts operated in both breasts. Results: Results were considered satisfactory, from the reparative and aesthetic point of view, emphasizing the degree of improvement observed

\footnotetext{
${ }^{*}$ Corresponding author.
}

How to cite this paper: Resende, J.H.C., et al. (2015) Operative Technique for Correction of Gigantomastia, Using the Superior Pedicle, with Special Care for the Nipple-Papillary Grafts: A 13-Year Retrospective Study. Modern Plastic Surgery, 5, 34-46. http://dx.doi.org/10.4236/mps.2015.53007 
in women undergoing technique. Discussion: We can say that during all this time of aesthetic and therapeutic-restorative surgery, due to its realization in a single surgical time, there was big impact on the aesthetics of patients and on their families, even taking into account possible complications in the post-operative. Conclusion: The superior pedicle technique, performed as described here, is a safe and reliable procedure in patients with severe gigantomastia.

\title{
Keywords
}

\author{
Mammoplasty, Gigantomastia, Resende's Technique, Surgical Flaps, Bariatric Surgery, Obesity
}

\section{Introduction}

After many years working in reconstructive surgery, I found myself facing an initial situation that caught my attention on women with gigantomastia and what this anomaly caused, such as pain, shame, difficulty in finding a job, affective relationships, clothing, mobility, physical discomfort, besides psychological disorders. I knew, too, of the difficulties of performing these breast-reduction surgeries in an one-step procedure due to technical medical-surgical and nursing care performed with the grafts of the nipple-areolar complex.

There are few cases of breast surgery in which the nipple-areolar complex grafts are performed, except when there is no condition to use pedicles or rotations. On the other hand, this procedure is indicated in all cases of mastectomy for cancer, traumatic losses and gigantomastias. These grafts are made based on the natural anatomy of the reconstructed breast, usually near the right or left hemi-clavicular line, near the 5th intercostal space. The material used can be the local areola and nipple itself or from the contralateral breast. There are cases in which the nipple is rebuilt with the skin of reconstruction itself or with the excess of nipple from the non-rebuilt side. Other options include the removal of donor skin of the inguinal region or near from the lips of the vagina.

In the cases reported, we evaluated only the grafts performed of the very areolas and nipples taken in the perioperative period, to be decorticated and reimplanted on the new remaining breast, put after amputation of the gigantomastia existing before the body relief surgery. These are cases of public health, composed by service sector professionals such as washerwomen and cleaners that in their daily lives experience major constraints in the performance not only of their labor activities, but also those of their own daily life, with significant impacts on their quality of life, including the psycho-affective sphere.

The initial procedure, the amputation of giant breasts, is called body relief surgery. It is of utmost importance, since it restores impaired mobility by excessive load of the breasts, whose average value per anatomical piece varies between 4 and $8 \mathrm{~kg}$. However, the occurrence of higher levels is not ignored, particularly when the gigantomastia is associated with obesity. In morbidly obese patients, a quite frequent comorbidity, body relief surgery is indicated previously to the realization of bariatric procedures, contributing to the reduction of the cardiorespiratory risk by reducing blood pressure over the rib cage.

The reason why such grafts are used and not the elevation of the nipple-areolar complex is in the respect for the principles of the vascular pedicles, which advocates that they should not be performed when the ratio base:height is greater than 2:1. In the proportions 3:1 or more, the previous autonomy rules must be observed, in a context that it would be logical to consider the cost-benefit relations not only in terms of operative time and days of hospitalization, but also accounting for financial losses and losses on reconstruction and aesthetics of patients. It is noteworthy always remembering the pre-, peri- and postoperative care and the correct execution of the technique employed.

\section{Method}

We performed a retrospective study of all obese patients with severe gigantomastia who underwent reduction mammaplasty with an operative technique using the superior pedicle (Resende's technique), with special care for the nipple-papillary grafts. The study was carried out at a single federal healthcare institution, Hospital dos Servidores do Estado (Rio de Janeiro, RJ, Brazil), between 2001 and 2013, in a total of 30 cases. This operative technique was presented at first time in 1980, in an International Congress of Plastic Surgery, carried out in Fortaleza, CE, Brazil. The description of Resende’s technique was included in the next section. 
Between diagnosis and surgical intervention itself there was a wait of about six months, during which all patients were advised of the multidisciplinary team and participated in support obese patient groups. Such interventions, involving the work of doctors, nurses, nutritionists, psychologists and physiotherapists, are intended to offer patients the means of promotion of the necessary changes in their lifestyles, as well as reconciling their expectations with outcomes that can be achieved. Special attention is paid to possible complications, with emphasis on self-care strategies that can contribute in important ways to prevent them.

Follow-up was 2 years (range 1 to 3). In assessing the results, three indicators were considered: occurrence of complications, patient satisfaction and impact on their quality of life. The first indicator of objective nature was evaluated according to the usual propedeutic procedures, complemented by photographic record for monitoring and documentation. The two other indicators, subjective in nature, were evaluated both from spontaneous comments and/or during consultations with the various professionals, especially nurses and psychologists. This monitoring iis a part of the protocol of surgical management of cases of Gigantomastia adopted in this public healthcare institution. Records about these indicators are contained in patients' medical records. This dynamic, it should be noted, was not developed specifically for the study in question, but the inclusion of data available was made by consent of each patient in accordance with the Brazilian legislation. The conformity in relation to ethical and legal aspects has been carefully evaluated and the study was authorized by the Resolution CAAE No. 05275613.4.0000.5259.

\section{Results}

Gigantomastia (Figure 1) is a type of breast hypertrophy [1]-[3], generally female, occurring most commonly in obesity. The first women operated, at the end of 1970's decade, had tried various diets and even though having lost a few pounds, the breasts were still making it impossible to perform any kind of work within the expectations of contractors [4] [5].

The visible deformity, as well as the prejudices and social stereotypes associated with it, often were impediments, explicit or not, for the contracting of the services of these workers. Many of them had history of burns or accidents due to the size of the breasts. Existing techniques at the time [6]-[8], with use of nipple-areolar complex [9] [10] demanded the performance of two or more surgical steps in order to avoid suffering or even necrosis of the areola and nipples [11] [12]. And so it was developed by Resende the technique of amputation of the giant part of the breast [13], on its bottom, leaving a pedicle of 12 - 14 centimeters, with an upper base [14] (Figure 2), to be invaginated and attached to the pectoralis major muscle, giving to the future breast, a cone shape, with final scar in inverted “ $T$ ” form [15] [16]. Leaving the nipple-pareolar complex donor well exposed (Figure 3). Marking with areola maker the areola in the perioperative (Figure 4). Removing slimly the nipple-areolar complex (Figure 5). We leave the flap with superior pedicle decorticated marked and observe that the nipple-papillary complex has already been removed, using a maneuver of Schwartzman (Figure 6). The nipple-areola is immersed in saline solution (Figure 7). Continuing the surgery, the amputated piece is cut up following the previous marking of the technique. After the surgery, with the breasts mounted and sutured, it should be marked, with the same areola maker, the site of the future graft (Figure 8). Decorticating carefully the nipple-areolar complex (Figure 9). Preparing the receptor site for the graft and placing it carefully (Figure 10). The graft is sutured with interrupted sutures (Figure 11). Four stitches with long nylon 4.0 yarns are placed to fix the Brown's dressing (Figure 12). We put these dressings and tie them (Figure 13). Then, we have the immediate postoperative ready to receive ointment, gauze and crepe bandage or similar or appropriate bra (Figure 14). After four days, we removed the bandages and observed the full adhesion of the graft, which is still with separate stitches (Figure 15). After four months, we observed that the scars are noticeable in inverted "T", but with better aesthetic conditions, giving back to patients improvement in all aspects of life, including social, emotional and sexual spheres (Figure 16). The surgical specimen of the patient in question amounted to $10 \mathrm{~kg}, 5 \mathrm{~kg}$ in each side (Figure 17). We can see, in the postoperative after 4 months, the decrease in physical discomfort and better health and posture of the operated patient (Figure 18). Analyzing the left breast preoperatively, with the obese body, we can assess the damage caused by gigantomastia (Figure 19) and comparing it to the postoperative after 4 months (Figure 20), we can evaluate the benefits caused by this procedure. We showed in close-up the nippleareolar complex fully integrated in the breast in the postoperative after one year (Figure 21). With closer focus, we can see details of the result after one year (Figure 22).

The surgical specimens ranged from 4 to $8 \mathrm{~kg}$ in average. Table 1 shows details about amounts of tissue removed. 


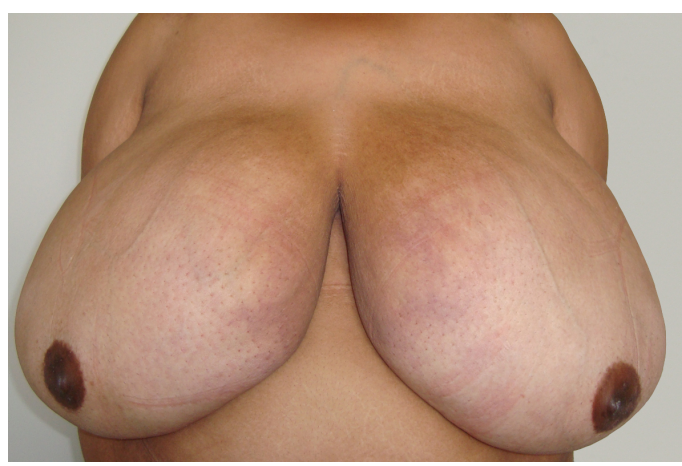

Figure 1. Preoperative of gigantomastia.

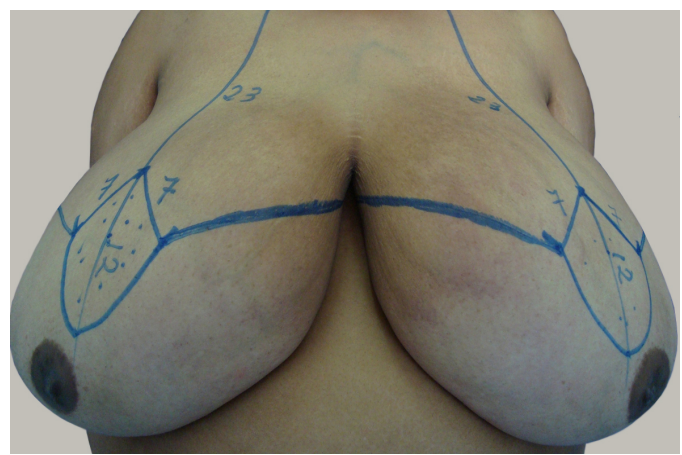

Figure 2. Marking the "Resende's technique" to gigantomastia correction.

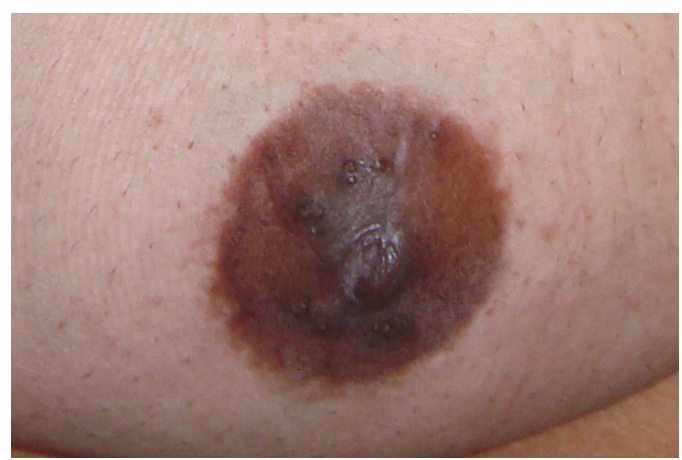

Figure 3. Areola and nipple in preoperative.

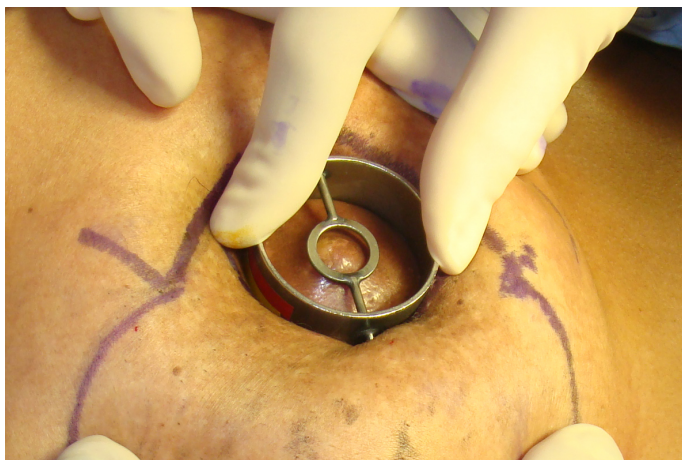

Figure 4. Marking with areola maker in the perioperative. 


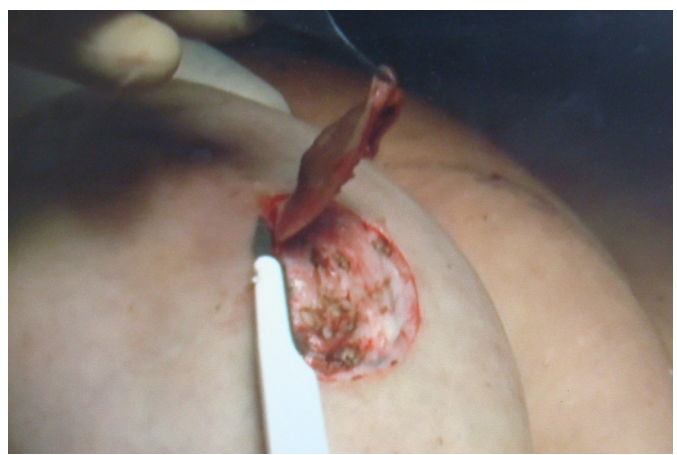

Figure 5. Removal of the nipple-areolar complex.

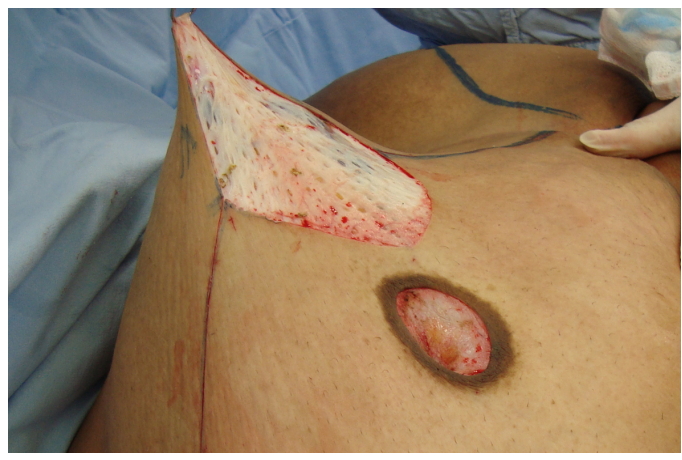

Figure 6. Flap with superior pedicle decorticated and removal of nipple-areolar complex.

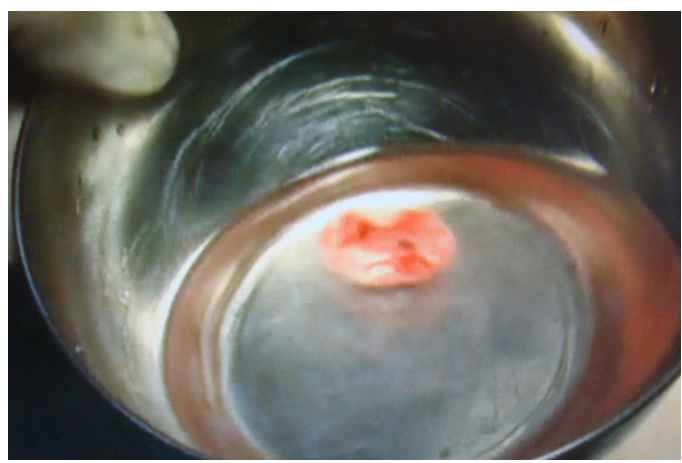

Figure 7. Areola and nipple in saline solution.

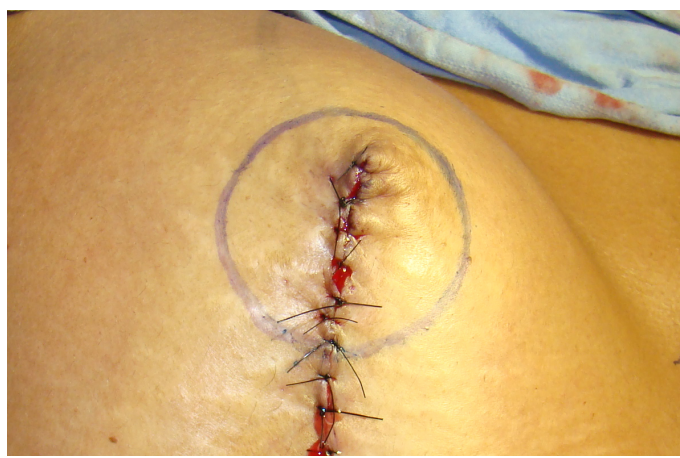

Figure 8. Marking with areola maker the future receptor site of the physiological graft. 


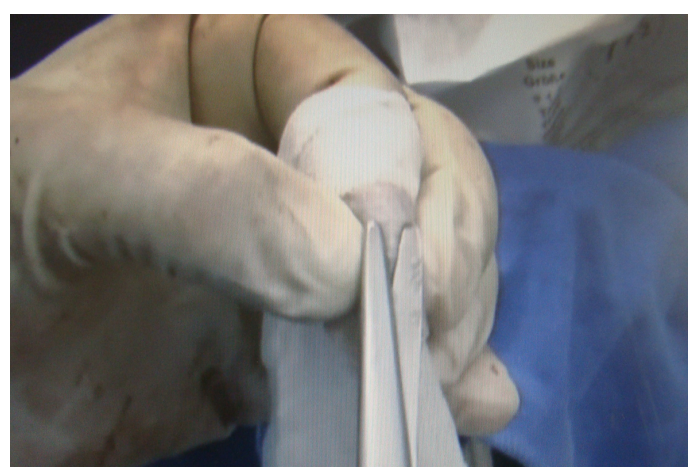

Figure 9. Careful decortication of nipple-areolar complex.

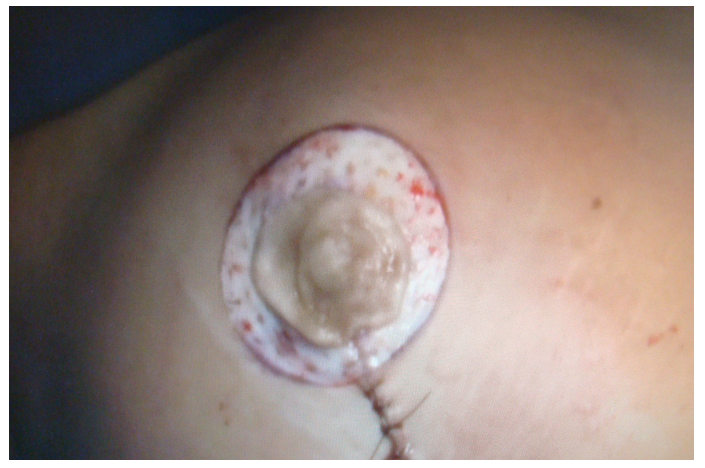

Figure 10. Graft placed on the decorticated area.

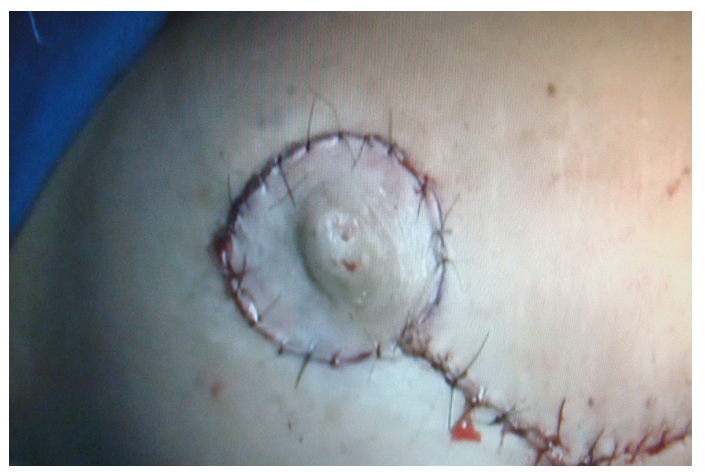

Figure 11. Graft sutured with interrupted sutures.

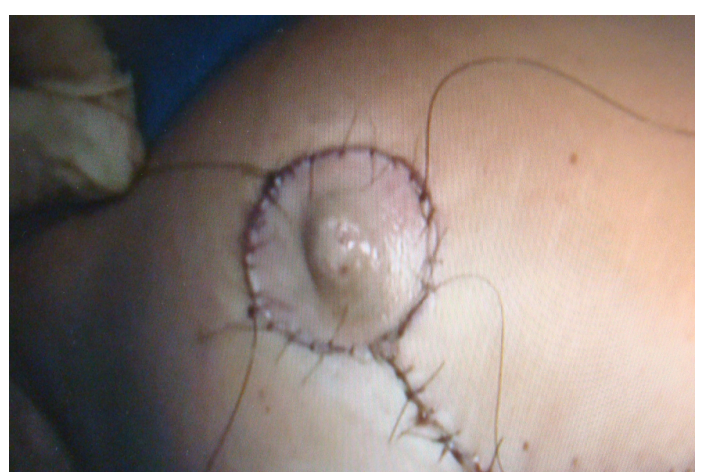

Figure 12. Long stitches to hold the brown's dressing. 


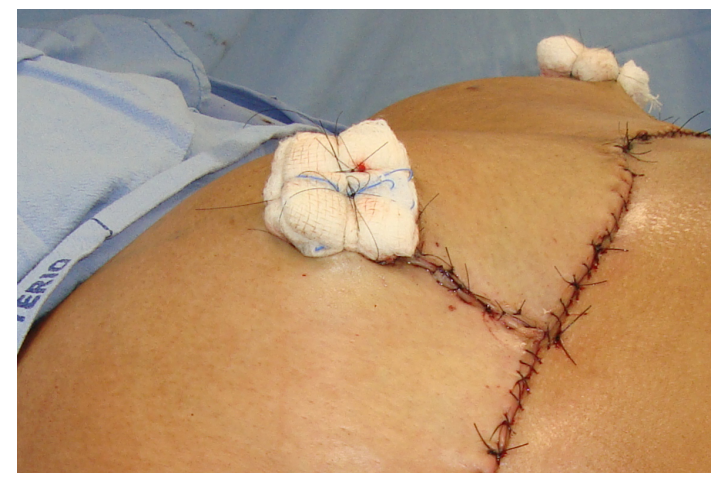

Figure 13. Brown’s dressing finished.

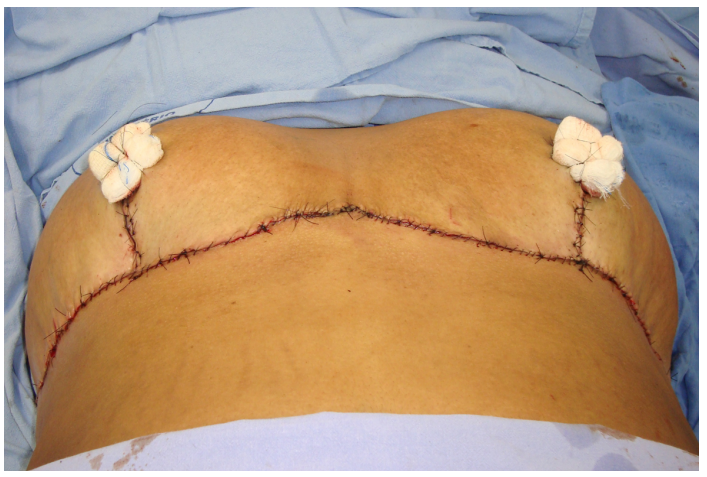

Figure 14. Immediate postoperative.

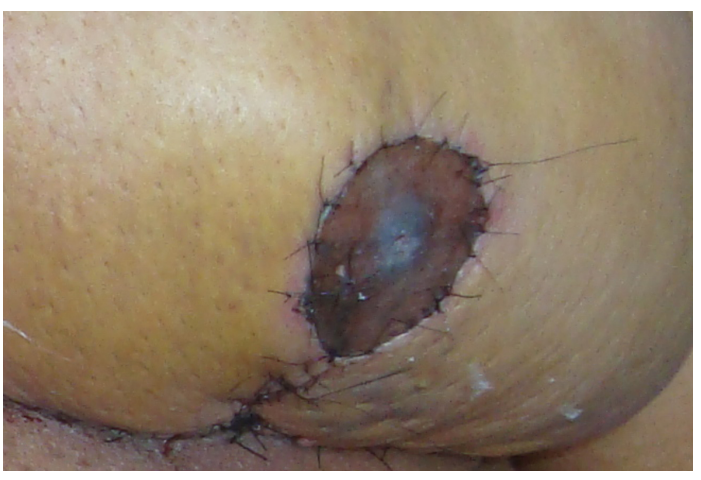

Figure 15. Postoperative on the 4th day.

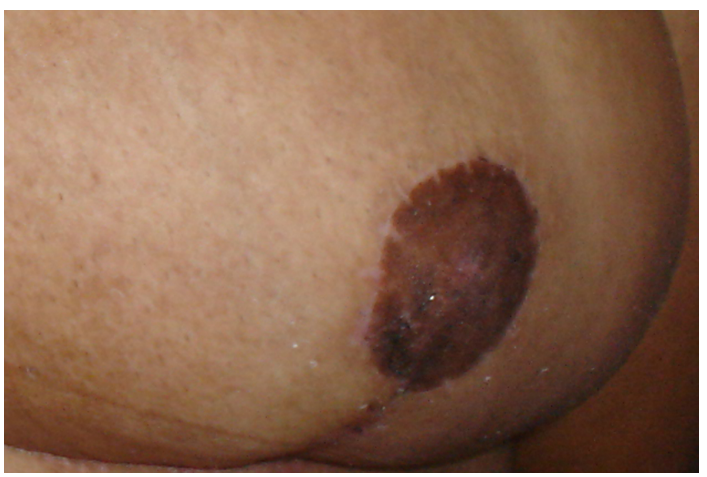

Figure 16. Postoperative after 4 months. 


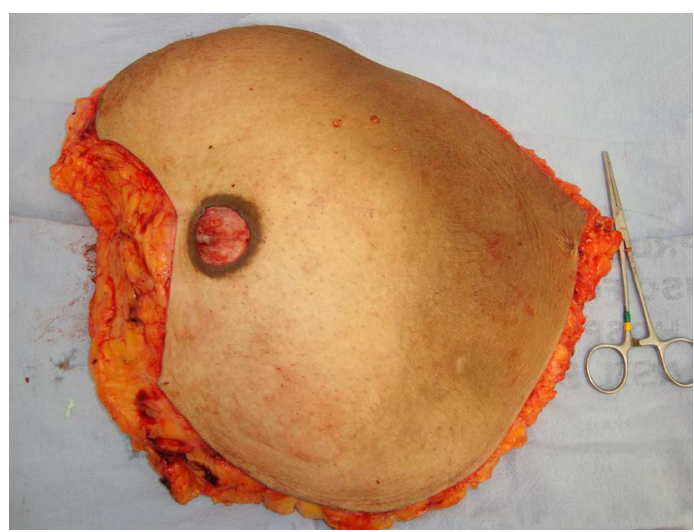

Figure 17. Unilateral surgical specimen with 5 kg.

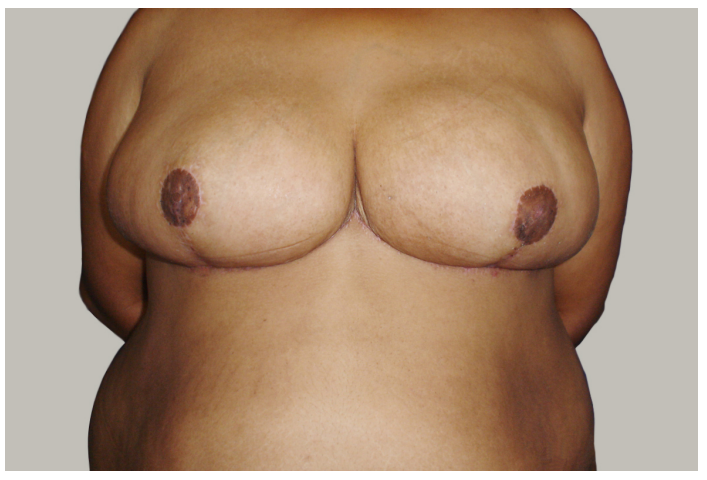

Figure 18. Front postoperative after 4 months.

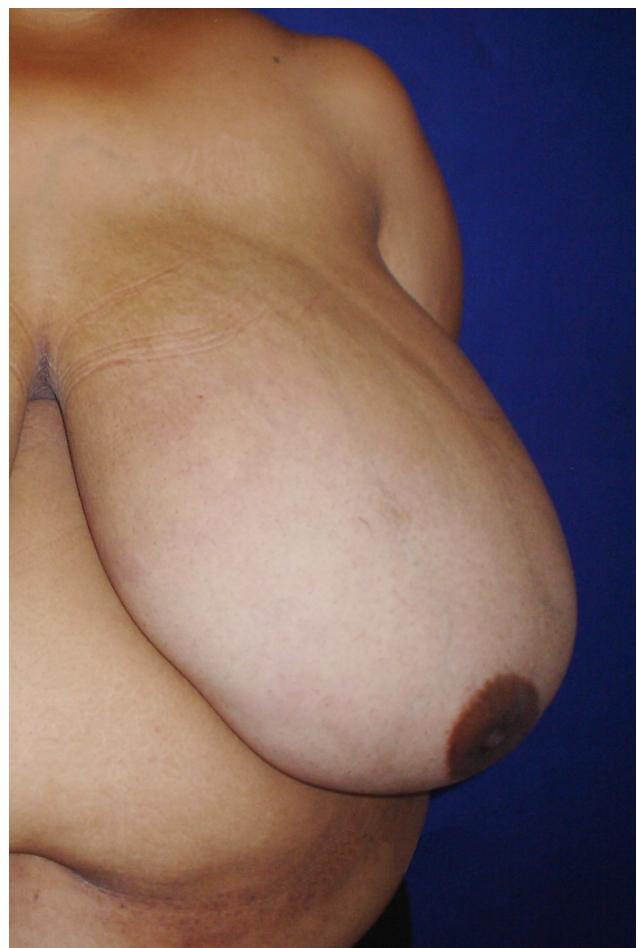

Figure 19. Preoperative of left breast focusing on the location of the areola and nipple. 


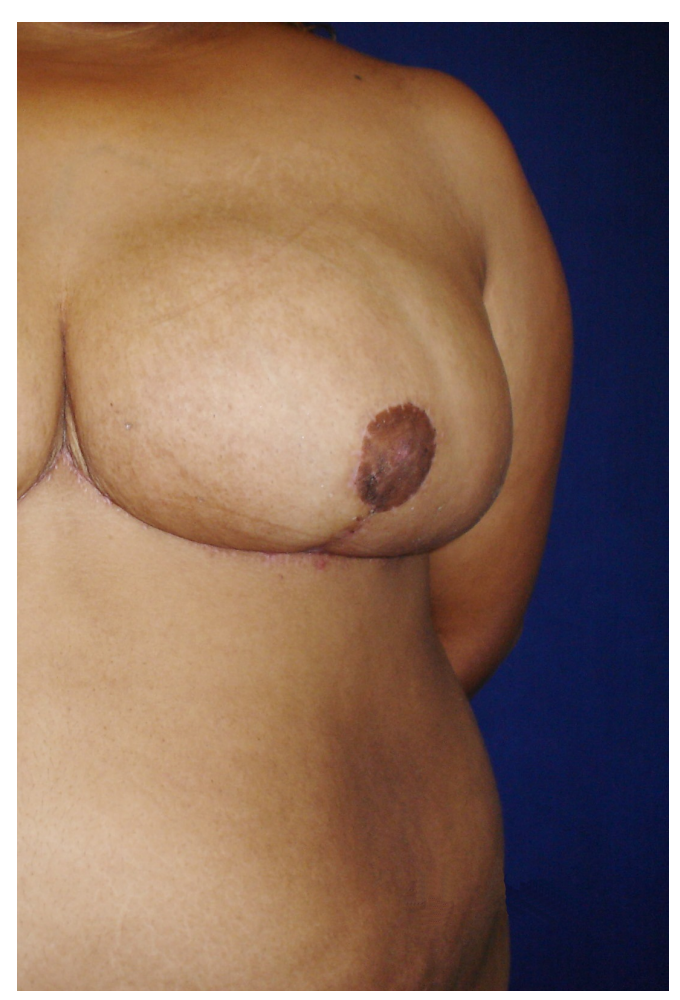

Figure 20. Postoperative of left breast after 4 months.

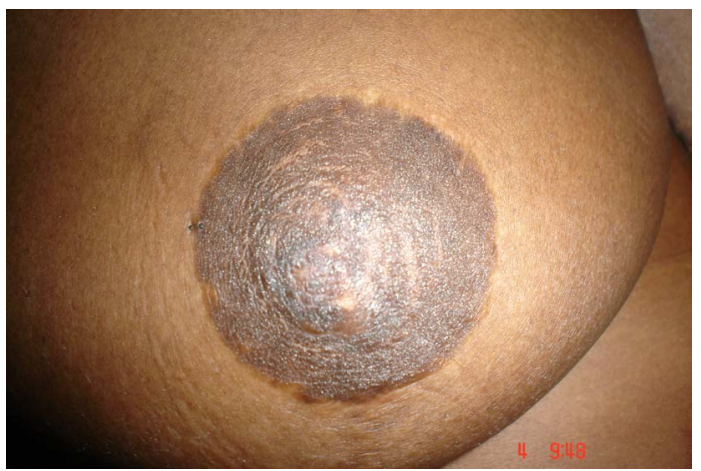

Figure 21. Focus of nipple-areolar complex after one year.

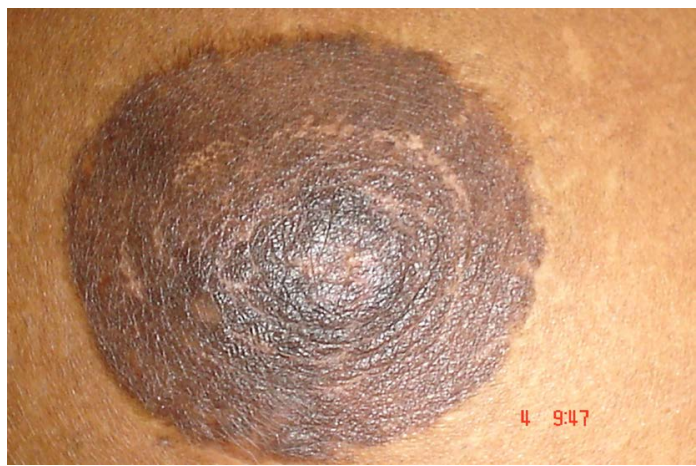

Figure 22. Focus of nipple-areolar complex after 1 year and closer. 
Table 1. Details about amounts of tissue removed.

\begin{tabular}{|c|c|c|c|c|}
\hline \multirow{2}{*}{ Order } & \multirow{2}{*}{$\begin{array}{c}\text { Age } \\
\text { (in years) }\end{array}$} & \multicolumn{2}{|c|}{ Breast amount extirpated } & \multirow{2}{*}{$\begin{array}{c}\text { Total weight extirpated } \\
\text { (in } \mathbf{k g}^{*} \text { ) }\end{array}$} \\
\hline & & Right breast (in kg*) & Left breast (in kg*) & \\
\hline 1 & 41 & 18 & 14 & 32 \\
\hline 2 & 30 & 4 & 5 & 9 \\
\hline 3 & 58 & 2.5 & 3 & 5.5 \\
\hline 4 & 42 & 3 & 4 & 7 \\
\hline 5 & 52 & 4.5 & 4 & 8.5 \\
\hline 6 & 54 & 3 & 3 & 6 \\
\hline 7 & 43 & 2 & 2.5 & 4.5 \\
\hline 8 & 48 & 3.5 & 4 & 7.5 \\
\hline 9 & 50 & 4 & 4 & 8 \\
\hline 10 & 57 & 2.5 & 2 & 4.5 \\
\hline 11 & 43 & 1.5 & 2.5 & 4 \\
\hline 12 & 47 & 3.5 & 4.5 & 8 \\
\hline 13 & 51 & 4 & 5 & 9 \\
\hline 14 & 45 & 1.5 & 1.5 & 3 \\
\hline 15 & 49 & 2.5 & 2 & 4.5 \\
\hline 16 & 38 & 4 & 4 & 8 \\
\hline 17 & 60 & 3 & 4.5 & 7.5 \\
\hline 18 & 57 & 3 & 4 & 7 \\
\hline 19 & 47 & 2 & 2 & 4 \\
\hline 20 & 56 & 1.5 & 2.5 & 4 \\
\hline 21 & 60 & 4 & 3.5 & 7.5 \\
\hline 22 & 51 & 3 & 3 & 6 \\
\hline 23 & 48 & 2 & 3 & 5 \\
\hline 24 & 54 & 3 & 4 & 7 \\
\hline 25 & 59 & 3.5 & 4 & 7.5 \\
\hline 26 & 26 & 4 & 4 & 8 \\
\hline 27 & 55 & 3.5 & 4.5 & 8 \\
\hline 28 & 18 & 3 & 2.5 & 5.5 \\
\hline 29 & 35 & 2 & 3 & 5 \\
\hline 30 & 54 & 2 & 2 & 4 \\
\hline Media & 47.6 & 3.8 & 4.0 & 7.6 \\
\hline
\end{tabular}

${ }^{*}$ kg: kilograms.

Patient satisfaction after breast reduction with the superior pedicle technique described above was high as $98 \%$, as was good the nipple sensation and the shape over the time. The mean follow-up was 2 years (range 1 to $3)$. The revision rate was very low and the complications were minor and self-limiting. Less than 5\% of cases showed little sufferings of the graft, which healed spontaneously [17]-[32]. In 2 cases, after 6 months of surgery, it was asked to carry out tattoo pigment similar to the color of the areola. We present below the case whose pre and postoperative of nipple-areolar grafts kept the normal appearance, acceptable from the reparative and aesthetic point of view, giving back to the patient better social and family conditions. 
Among the most heard reports, it can be highlighted for their representation in the universe considered, the following statements: "I have never used a T-shirt, I would not take the clothes close to anyone"; "I was dismissed from several jobs because of the size of my breasts"; "My husband left me"; "I would not be invited to anything," etc. We had a patient who, for a long time, was considered the carrier of the largest breasts surgical specimen ever published, from which we removed $32 \mathrm{~kg}$ in total.

\section{Discussion}

The amputation with free nipple graft is now barely used since the introduction of the pedicle techniques, in view of the complications such as loss of nipple areola complex, hypopigmentation and poor breast projection. The pedicles procedures have the unquestionable advantage of producing a high degree of reliability and safety for the nipple areola complex, in terms of both sensation and blood supply [33]. Our results in this number of cases are compatible with a previous report.

Most of the pedicle techniques are a feasible solution for any degree of ptosis, but only few can be considered reliable and suitable for severe gigantomastia. Although currently most of the breast reduction techniques have focused their interest on the shape of the breast as well as limiting the cutaneous scars, it is a challenge to prevent the extended scars in patients with severe gigantomastia [33]-[38].

It is currently observed renewed interest in the development of breast reduction universal use techniques; that is, that can be used regardless of the volume of the breasts to be operated. In addition, also points up the interest in this technique is simple and the curve of her learning is accelerated. Of course, it is obvious merit goal, but our personal experience does not allow it to be seen without reservation. However, the recent literature has reiterated that possibility [33]-[35].

Surgical treatment of gigantomastia using graft of the nipple-areolar complex is a surgical option that requires skills and scientific knowledge with mastery of the technique, but it may give back a better quality of life to these women carriers of a type of physical deformity and, most importantly, the joy to live and work with respect and dignity, without discrimination, recovering self-esteem, joy and confidence due to the new look. Although it is a "long process" of monitoring at the clinic, we, as health professionals, doctors and nurses, feel privileged in our interventions, since we have done everything we could so that they can reach the best possible conditions of well-being and will to live [36]-[39].

Gigantomastia is a physically disabling condition characterized by excessive breast hypertrophy. In the literature, it is arbitrarily defined as breast enlargement requiring reduction ranging from 800 to $2000 \mathrm{~g}$ per side. The authentic pandemia of obesity, outlined from the end of Second World War and most severe from the last three decades, among other adverse impacts, is responsible for an important increasing of number of cases of gigantomastia. In addition, the involvement of the youngest is another face of a problem that, in essence, impose the surgical management of increasingly large breasts [36] [40]-[42]. In the present study, we observed an average weight to be extirpated of $7.8 \mathrm{~kg}$, considering both breasts, a media of $4.0 \mathrm{~kg}$ from the right side and $3.8 \mathrm{~kg}$ from the left one.

Regarding the multidisciplinary team, it should be noted the importance of cooperative and integrated practice for achieving synergistic results oriented to promote welfare and health of patients. However, by their extent and impact, it should be highlighted once more that the importance of nursing. While in Brazil the scene of these professionals is still far from exhausting its potential, recent publications offer an interesting and diverse landscape [43]-[45].

\section{Conclusion}

Hypertrophy of breasts addresses versatility, safety, and predictability in breast reductions. The superior pedicle technique, performed as described here, is a safe and reliable procedure in patients with severe gigantomastia.

\section{References}

[1] Gillies, M. and McIndoe, A.H. (1939) The Technique of Mammaplasty in Conditions of Hypertrophy of the Breast. Surgery, Gynecology \& Obstetrics, 68, 658.

[2] Pitanguy, I. (1960) Breast Hypertrophy. Transactions of International Society of Plastic Surgeous, Edinburgh, E.S. Livingstone, London. 
[3] Pitanguy, I. (1967) Surgical Treatment of Breast Hypertrophy. British Journal of Plastic Surgery, 20, 78. http://dx.doi.org/10.1016/S0007-1226(67)80009-2

[4] McKissock, P.K. (1972) Reduction Mammaplasty with a Vertical Dermal Flap. Plastic and Reconstructive Surgery, 49, 245. http://dx.doi.org/10.1097/00006534-197203000-00001

[5] Millard Jr., D.R., Devine Jr., J. and Warren, W.D. (1971) Breast Reconstruction: A Plea for Saving the Uninvolved Nipple. American Journal of Surgery, 122, 763-764. http://dx.doi.org/10.1016/0002-9610(71)90441-7

[6] Dufourmentel, C. and Mouly, R. (1961) Plastic mammaire por la méthode obliqúe. Annales De Chirurgie Plastique Esthetique, 6, 45-48.

[7] Dufourmentel, L. (1927) La mastopéxie par deplacement souscutané avec transposition du mamelon. Bulletin Mensuel de la Société de Chirurgie de Paris.

[8] Inforzato, J.C.B., et al. (2006) Gigantomastia-Técnica do pedículo inferior-Abordagem pessoal, Atualização em Cirurgia Plástica Estética e Reconstrutiva, São Paulo, Robe Editorial, 699.

[9] Biesenberger, H. (1928) Blutversorgung und Zirkuläre Umschnedung des Warzenhofes. Zentralblatt für Chirurgie, 55, 2385.

[10] Morestin, H. (1903) De lablation esthétique des tumeurs du sein. Bulletin Mensuel de la Société de Chirurgie de Paris, 29, 562.

[11] Cronin, E.D., Humphreys, D.H. and Ruiz-Razura, A. (1988) Nipple Reconstruction: The S Flap. Plastic and Reconstructive Surgery, 81, 783-787. http://dx.doi.org/10.1097/00006534-198805000-00026

[12] Banducci, D.R., Le, T.K. and Hughes, K.C. (1999) Long-Term Follow-Up of a Modified Anton-Hartranpf Nipple Reconstruction. Annals of Plastic Surgery, 43, 467-470. http://dx.doi.org/10.1097/00000637-199911000-00001

[13] Kraske, H. (1923) Die Operation der atroplischen und Hypertroplischen Hangebrust. Munchener Medizinische Wochenschrift, 60, 672.

[14] Aufricht, G. (1949) Mamaplasty for Pendulous Breast. Empiric and Geometric Planning. Plastic and Reconstructive Surgery, 4, 13-29. http://dx.doi.org/10.1097/00006534-194901000-00002

[15] Gruber, R.P. (1979) Nipple-Areola Reconstruction: A Review of Techniques. Clinics in Plastic Surgery, 6, 71-83.

[16] Sinder, R. (1963) Tese apresentada na Universidade Federal do Rio de Janeiro-Mamoplastia em “T” invertido. Technique of Breast Reduction; Transposition of the Nipple on a Cutaneous Vascular Pedicle. Acta Chirurgica Scandinavica, 126, 453-465.

[17] Resende, J.H.C. (2003) Gigantomastia. In: Cirurgia Plástica Fundamentos e Arte: Cirurgia Estética, MEDSI, São Paulo, Vol. 1, 561.

[18] Weiner, D.L., Aiache, A.E., Silver, L. and Tittiranonda, T. (1973) A Single Derman Pedicle for Nipple Transposition in Subcutaneous Mastectomy, Reduction Mammaplasty, or Mastopexy. Plastic and Reconstructive Surgery, 51, 115120. http://dx.doi.org/10.1097/00006534-197302000-00001

[19] Thomas, T.G. (1985) On the Removal of Benign Tumors of the Mamma without Mutilation of the Organ. Plastic and Reconstructive Surgery, 76, 476.

[20] Thorek, M. (1989) Possibilities in the Reconstruction of the Human Form. Aesthetic Plastic Surgery, 13, 55-58.

[21] Regnault, P. (1967) Indications for Breast Augmentation. Plastic and Reconstructive Surgery, 40, 524-529. http://dx.doi.org/10.1097/00006534-196740060-00002

[22] Adams, W.M. (1949) Labial Transplant for Correction of Loss of the Nipple. Plastic and Reconstructive Surgery, 4, 295-298. http://dx.doi.org/10.1097/00006534-194905000-00009

[23] Farhadi, J., Maksvytyte, G.K., Schaefer, D.J., Pierer, G. and Scheufler, O. (2006) Reconstruction of the Nipple-Areola Complex: An Update. Journal of Plastic, Reconstructive \& Aesthetic Surgery, 59, 40-53. http://dx.doi.org/10.1016/j.bjps.2005.08.006

[24] Tostes, R.O.G., Silva, K.D.A., Andrade Jr., J.C.C.G., Ribeiro, G.V.C. and Rodrigues, R.B.M. (2005) Reconstrução do mamilo por meio da técnica do retalho C-V: Contribuição à técnica. Revista Brasileira de Cirurgia Plástica, 20, 36-39.

[25] Shestak, K.C. and Nguyen, T.D. (2007) The Double Opposing Periareola Flap: A Novel Concept for Nipple-Areola Reconstruction. Plastic and Reconstructive Surgery, 119, 473-480. http://dx.doi.org/10.1097/01.prs.0000246382.40806.26

[26] Rosique, M.J.F. and Arantes, H.L. (2011) Reconstrução do Complexo Aréolopapilar e Refinamentos Técnicos. In: Mélega, J.M., Ed., Guanabara Koogan, 762-772.

[27] Eskenazi, L. (1993) A One-Stage Nipple Reconstruction with the "Modified Star” Flap and Immediate Tattoo: A Review of 100 Cases. Plastic and Reconstructive Surgery, 92, 671-680. http://dx.doi.org/10.1097/00006534-199309001-00017 
[28] Spear, S.L., Convit, R. and Little, J.W. (1989) Intradermal Tattoo as an Adjunct to Nipple-Areola Reconstruction. Plastic and Reconstructive Surgery, 83, 907-911. http://dx.doi.org/10.1097/00006534-198905000-00027

[29] Lamartine, D.J., Cintra Jr., R., Daher, C.J., Cammarota, M.C., Galdino, J., Pedroso, D.B. and Cintra, R.H. (2013) Nipple-Areola Reconstruction Using the Double Opposing Flap Technique. Revista Brasileira de Cirurgia Plástica, 28, 233-240. http://dx.doi.org/10.1590/S1983-51752013000200011

[30] Passo, T.R. (1925) La correction esthétique du prolapsus mammaire par Le procede de la transposition du mamelon. La Presse Medicale, 33, 317.

[31] Schwartz, A.W. (1976) Reconstruction of the Nipple and Aréola. British Journal of Plastic Surgery, 29, $230-233$. http://dx.doi.org/10.1016/S0007-1226(76)90062-X

[32] Resende, J.H.C. (1980) Técnica cirúrgica para gigantomastia. Ver. CBS (Centro de Ciências Biológicas e da Saúde), Rio de Janeiro, 80-89.

[33] Lugo, L.M., Prada, M., Kohanzadeh, S., Mesa, J.M., Long, J.N. and de la Torre, J. (2013) Surgical Outcomes of Gigantomastia Breast Reduction Superomedial Pedicle Technique-A 12-Year Retrospective Study. Annals of plastic surgery, 70, 533-537. http://dx.doi.org/10.1097/SAP.0b013e31827c7909

[34] Nadeau, M.H., Gould, D.J., Macias, L.H., Spring, M.A. and Stevens, W.G. (2015) Superior Pedicle Technique of Reduction Mammaplasty: A Stepwise Approach. Aesthetic Surgery Journal, 35, 94-104. http://dx.doi.org/10.1093/asj/sju011

[35] Hunter-Smith, D.J., Smoll, N.R., Marne, B., Maung, H. and Findlay, M.W. (2012) Comparing Breast-Reduction Techniques: Time-to-Event Analysis and Recommendations. Aesthetic Plastic Surgery, 36, 600-606. http://dx.doi.org/10.1007/s00266-011-9860-3

[36] Resende, J.H.C. (2009) Técnica de Resende para correção de Gigantomastia—Cirurgia de Alívio Corporal, Tratado de Cirurgia Plástica na Obesidade, Rio de Janeiro, Ed. Rubio, 357-365.

[37] Resende, J.H.C. (1980) Técnica para gigantomastia. Apresentado no XVII Congresso Brasileiro de Cirurgia Plástica e $V$ Congresso Brasileiro de Cirurgia Estética, Fortaleza, Novembro.

[38] Strömbeck, J.G. (1960) Mammaplasty: Report of a New Technique Based on the Two-Pedicle Procedure. British Journal of Plastic Surgery, 13, 79-90. http://dx.doi.org/10.1016/s0007-1226(60)80014-8

[39] Tamerin, J.A. (1951) A Mammaplastic Procedure. Plastic and Reconstructive Surgery, 7, 288-295. http://dx.doi.org/10.1097/00006534-195107040-00003

[40] Manahan, M.A., Buretta, K.J., Chang, D., Mithani, S.K., Mallalieu, J. and Shermak, M.A. (2015) An Outcomes Analysis of 2142 Breast Reduction Procedures. Annals of Plastic Surgery, 74, 289-292. http://dx.doi.org/10.1097/SAP.0b013e31829d2261

[41] Coriddi, M., Koltz, P.F. and Gusenoff, J.A. (2011) Reduction Mammaplasty, Obesity, and Massive Weight Loss: Temporal Relationships of Satisfaction with Breast Contour. Plastic and Reconstructive Surgery, 128, 643-650. http://dx.doi.org/10.1097/PRS.0b013e318221da6b

[42] Koltz, P.F., Sbitany, H., Myers, R.P., Shaw, R.B., Patel, N. and Girotto, J.A. (2011) Reduction Mammaplasty in the Adolescent Female: The URMC Experience. International Journal of Surgery, 9, 229-232. http://dx.doi.org/10.1016/j.ijsu.2010.12.001

[43] Forster, E.M. (2013) Plastic Surgery Nursing: A Profession and a Passion. Plastic Surgical Nursing, 33, 4.

[44] Silinzieds, A., Simmons, L., Edward, K.L. and Mills, C. (2012) Nurse Education in Developing Countries—Australian Plastics and Microsurgical Nurses in Nepal. Plastic Surgical Nursing, 32, 148-155. http://dx.doi.org/10.1097/PSN.0b013e3182728267

[45] Hughes, S., Hughes, B. and Edward, K.L. (2011) Enhancing Nursing Practice Potential: Breast Free Flap Reconstruction Following Mastectomy. 